\title{
変動軸力と繰返し水平力を受ける鋼柱の弾塑性挙動に関する実験的研究 EXPERIMENTAL STUDY ON INELASTIC BEHAVIOR OF STEEL BEAM-COLUMNS SUBJECT TO VARYING AXIAL FORCE AND CYCLIC LATERAL LOAD
}

\author{
山崎真司*, 見波 進** \\ Shinji YAMAZAKI and Susumu MINAMI
}

\begin{abstract}
Beam-columns of multi-story frames are subject to varying axial forces induced by overturning moment and vertical vibrations during earthquakes. In order to investigate the effects of these varying axial forces on the inelastic behavior of beam-columns subject to cyclic horizontal forces, a series of experiments was conducted. The results obtained from analyses corresponded quite well to those of the experiments. From the results of both the experiments and analyses, the following conclusions can be drawn: (1) In the case of plane frames symmetrical to central vertical axis, varying axial forces induced by overturning moment have not a large effect upon the restoring force characteristics of stories. (2) The amount of energy dissipation of beam-columns, which are subject to cyclic vertical loads of about 5-10 cycles for the horizontal displacement of one cycle under displacement control, is almost equal to the amount in the case of the axial force being constant with its mean value.
\end{abstract}

Keywords : Steel beam-column, Loading test, Varying axial force, Cyclic lateral load, Load deflection curve 鋼柱, 載荷実験, 変動軸力, 繰返し水平力, 荷重変形関係

\section{1 序}

多層骨組の柱材は，地震時に転倒モーメントや鉛直振動による 変動軸力を受ける. 一定軸力下において一方向曲げあるいは綝返 し曲げを受ける鋼構造柱部材の弾塑性挙動についての実験的およ び解析的研究はすでに数多く行われている゙が, 変動軸力下での挙 動を扱った研究は少ない. 変動軸力下での柱部材挙動に関する実 験的研究として, 大井, 陳, 高梨による研究 ${ }^{22,3)}$, 山田, 秋山, 桑 村4kよる研究がある. 大井等は, 転倒モーメントによる変動軸力 を受ける柱について静的繰返し載荷実験及びオンライン実験を行っ ている. 山田等は, 一方向の曲げを受ける単純梁モデルについて, 軸力の変動パターンとして, 一定の場合, 材端回転角の増加と共 に単調増加する場合と単調堿少する場合の 3 種類についての実験を 行っている. 鉛直振動によってもたらされる様な変動軸力下で継 返し水平力を受ける場合の鋼柱の挙動に関する実験的研究はこれ まで報告されていない.

本研究では, 鉛直振動や転倒モーメントにより変動軸力を受け る多層骨組の下層部柱を想定し, 変動軸力と綝返し水平力を同時 に受ける鋼柱の弾塑性挙動に関する実験を行い, その性状につい て検討する. 単一の柱試験体のほか部分架構試験体についても赛 験を行い, 軸力の変動により柱と梁が交互に降伏する場合の挙動 についても調べる.

\section{2 実験}

\section{1 試験体}

試験体形状を図1に示す.試験体はAタイプ, Bタイプの2種類か ら成る. Aタイプ試験体は単一の柱試験体で，Bタイプ試験体は柱 と梁で構成される部分架構試験体である。試験体の柱梁材は溶接 組立断面材で, 断面形状は柱が箱形およびH形, 梁はH形である. 各断面を図2に示す.柱断面はC $1, \mathrm{C} 2, \mathrm{C} 3$ の3種類, 梁断面は $\mathrm{G} 1, \mathrm{G} 2$ 22種類で, $\mathrm{C} 3$ と 11 は同一である. 各断面共幅厚比は比較 的小さく，充分な塑性変形が可能な断面である. 使用鋼材は SS400, SM490の2種類で，各断面に対する鋼材を図2中の括弧内に 示している.

試験体一覧を表1に示す，試験体名は，試験体タイプ(AまたはB), 軸力載荷パターン(C，OVまたはUD. 2.4節参照), 試験体番号(1〜 4)を表している. 表中の柱細長比は, 座屈長さを $2 L_{C}\left(L_{C}\right.$ : 図 1 参 照)として算定した值である.

\section{2 鋼材の特性}

引張素材試験および試験体と同一断面を有する短柱圧縮試験よ り求めた応力と歪の関係を図3に示す. 図中の実線は試験結果を, 破線は解析に用いた応力歪関係(4.1参照)を示している. また, 降 伏点 $\sigma_{y}$, 引張強さ $\sigma_{u}$, 局部座届で決る最大応力 $\sigma_{B}$ 等の素材試験 結果一覧を表 2 に示す，なお，短柱圧縮試験体の長さは，断面幅の 3倍とした。

\footnotetext{
本論文の一部は参考文献8)に発表した。

* 東京都立大学大学院工学研究科建築学専攻 教授. 工博

** 東京都立大学大学院工学研究科建築学専攻 助手. 工修
}

Prof., Dept. of Architecture, Graduate School of Engineering, Tokyo Metropolitan Univ., Dr. Eng.

Research Assoc., Dept. of Architecture, Graduate School of Engineering, Tokyo Metropolitan Univ., M. Eng. 


\section{3 載荷方法}

加力装置を図4に示す．試験体を反力台の上に設置し，鉛直方向 用，水平方向用の 2 台のアクチュエータを用い，加力治具を介して 載荷する．鉛直載荷は荷重制御で，水平載荷は変位制御で行う

2.4 柱軸力の載荷パターン

柱軸力の載荷パターンは, C, OV, UDの3 種類である..載荷パ ターンCは, 一定軸力を載荷する場合である。載荷パターン OV，UDは，それぞれ転倒モーメントおよび鈆直振動による変動軸 力を想定したものである.

載荷パターンの例を図5に示す，水平変位および軸力は，載荷ス テップに対し原則として直線的に変化させているが，初期に行わ れた一部の実験では2方向の載荷制御を手動で行っていたため直線 的となっていないものもある. 図5の横軸は載荷ステップ，縦軸は 水平変位 $\delta_{H}$ および軸力 $P$ を示している， $\delta_{H}, P$ はそれぞれ降伏変 位 $\delta_{H p}$, 降伏軸力 $P_{\mathrm{y}}$ で除して無次元值で表している: ‘お, ‘本研究 では軸方向力および軸方向変形は压縮の場合を正として表わすこ ととする。

図5(1)は，載荷パターンOVの例である，水平変位を生じさせな い状態で長期鉛直荷重による軸力を想定した軸力(図5(1)における

$$
\text { 表 } 1 \text { 試験体一覧 }
$$

$\left.p_{0}\right)$ を載荷し，次に水平方向の正負の綝返し变位に対して，それと 同位相で平均を $p_{0}$ とする変動軸力を作用させる．この例では，ほ ぼ定振幅の変動軸力であるが, 漸増する変動軸力の場合について も行っている，実際の骨組における転倒モーメントによる変動軸 力は層せん断力にほぼ比例する．載荷パターンOVの場合, この条 件を満たしてはいないので，転倒モーメントによりもたらされる 変動軸力と厳密には対応するものではないが，この様な載荷実験 により転倒モーメントによる変動軸力を受ける部材挙動について の基本的性状を検討できると考えられる.

図5(2)は載荷パターンUDの例である。鋼構造多層建築では鉛直 振動の 1 次固有周期と水平振動の 1 次固有周期の比は $1 / 5 \sim 1 / 10$ 程度 である5!．そこで，本実験では，水平変位を生じさせない状態で長 期鉛直荷重による軸力を想定した軸力 $p_{0}$ を載荷し，次に水平方向 の繰返し1サイクルに対して約 5〜10サイクルの変動軸力を載荷し ている.この例では変動軸力は定振幅であるが，定振幅でない場 合もある。

各試験体の載荷パターンは実験結果と共に図13に示されている. また, 平均軸力および変動軸力振幅を軸力比で表したものを表にに 示している。

\begin{tabular}{|c|c|c|c|c|c|c|c|c|c|c|}
\hline \multirow[b]{2}{*}{ 試験体 } & \multirow{2}{*}{$\begin{array}{c}\text { 軸力 } \\
\text { 載荷 } \\
\lambda^{\circ} \text { 多-」 }\end{array}$} & \multicolumn{2}{|r|}{ 軸力比（P/P $)$} & \multicolumn{4}{|c|}{ 柱 } & \multicolumn{3}{|c|}{ 梁 } \\
\hline & & 平均 & 変動振幅 & 断面 & 鋼材 & $\begin{array}{c}\text { 材長 }\left(L_{c}\right) \\
\mathrm{mm}\end{array}$ & 細長比 & 断面 & 鍼材 & $\begin{array}{c}\text { 材長 }\left(L_{G}\right) \\
\mathbf{m m}\end{array}$ \\
\hline A-C-1 & $\mathrm{C}$ & 0.00 & 0.0 & $\mathrm{C} 1$ & SS400 & 450 & 20 & - & - & - \\
\hline A-C-2 & $\mathrm{C}$ & 0.29 & 0.0 & $\mathrm{Cl}$ & SS400 & 450 & 20 & - & - & $\therefore$ \\
\hline $\mathrm{A}-\mathrm{OV}-1$ & ov & 0.29 & \pm 0.29 (ほほ & $\mathrm{Cl}$ & SS 400 & 450 & 20 & - & - & - \\
\hline $\mathrm{A}-\mathrm{OV}-2$ & ov & 0.29 & 土0.29（ほほ一定） & $\mathrm{Cl}$ & SS400 & 700 & 31 & - & - & - \\
\hline $\mathrm{A}-\mathrm{OV}-3$ & ov & 0.50 & $\pm 0.3 \sim \pm 0.55$ (潮增) & $\mathrm{C} 3$ & SS 400 & 450 & 19 & - & - & - \\
\hline A-UD-1 & UD & 0.28 & \pm 0.28 (一定) & $\mathrm{C} 1$ & SS 400 & 450 & 20 & - & - & - \\
\hline A-UD-2 & UD & 0.19 & \pm 0.38 （一定） & $\mathrm{C} 1$ & SS 400 & 450 & 20 & - & - & - \\
\hline A-UD-3 & UD & 0.28 & \pm 0.28 （一定） & $\mathrm{C} 1$ & SS400 & 700 & 31 & - & - . & - \\
\hline A-UD-4 & UD & 0.59 & $\pm 0.1 \sim \pm 0.59$ (ランダム $)$ & $\mathrm{C} 2$ & SS 400 & 450 & 30 & - & - & - \\
\hline B-OV-1 & OV & 0.30 & 土0.4（ほほ一定） & $\mathrm{Cl}$ & SS 400 & 515 & 23. & G1 & SS400 & 915 \\
\hline B-UD-1 & UD & 0.30 & $\pm 0.2 \sim \pm 0.4($ ランダム) & $\mathrm{Cl}$ & SS 400 & 515 & 23 & $\mathrm{Gl}$ & SS400 & 915 \\
\hline B-UD-2 & UD & 0.30 & $\pm 0.15 \sim \pm 0.4$ (ランダム) & $\mathrm{Cl}$ & SS 400 & 515 & 23. & G1 & SS 400 & 915 \\
\hline B-UD-3 & UD & 0.35 & $\pm 0.28 \sim \pm 0.4$ (ランダム $)$ & $\mathrm{Cl}$ & SS 400 & 515 & 23 & G2 & SM490 & $915:$ \\
\hline
\end{tabular}

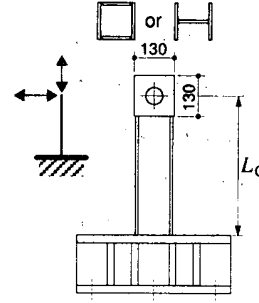

Aタイプ
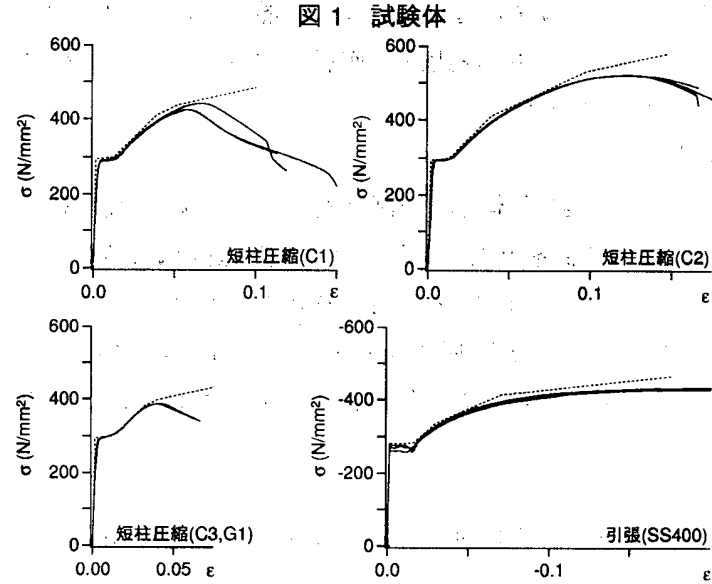

- 試験結果 ……解析用
図 1、試験体

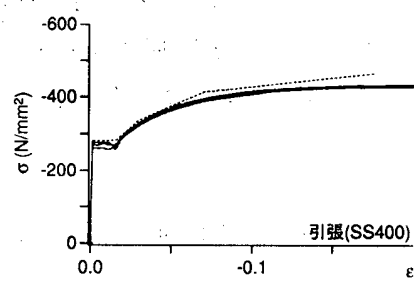

図 3 秦材の応力歪関係
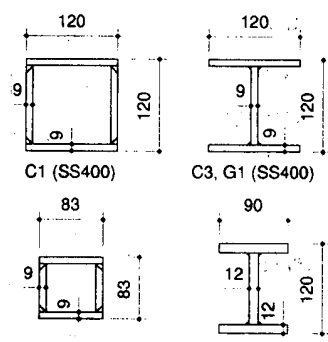
$\mathrm{G} 2$ (SM490)
図2 2 柱, 梁の断面形状
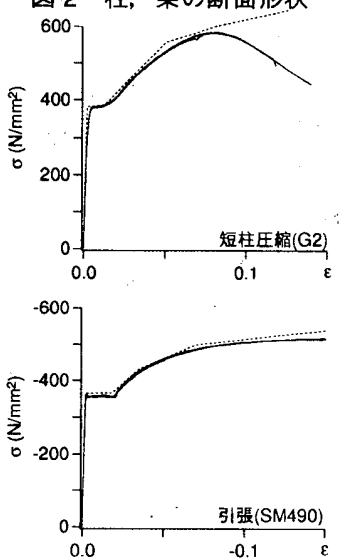

(2) SM490
3 解析

\section{1 解析法の概要}

本実験では；図1に示す様に単一柱あるいは柱梁そ れぞれ一部材から成る部分架構を対象としているが, ここに示す解析法は一般のラーメン構造平面モデルの 弾塑性解析に適用できるものである.

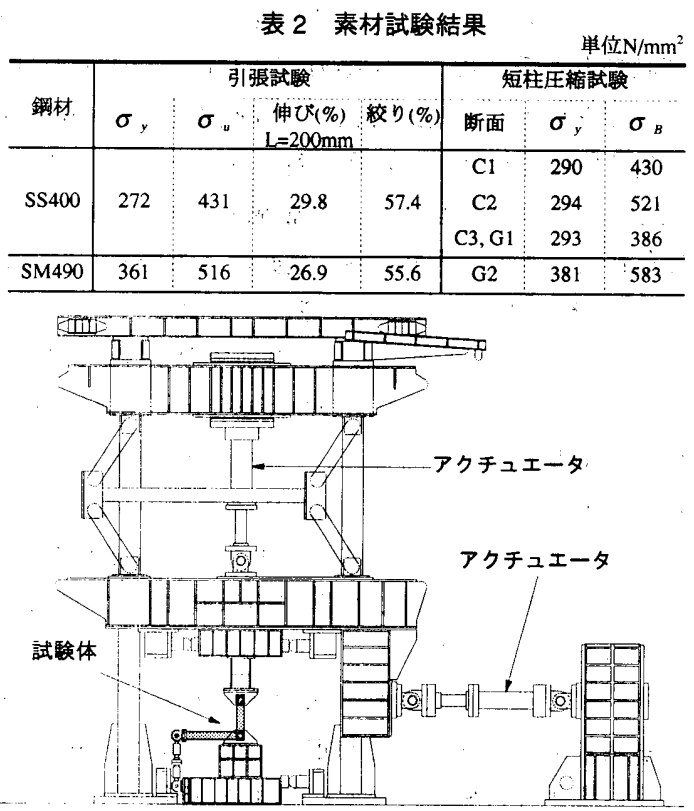

図 4 加力装置
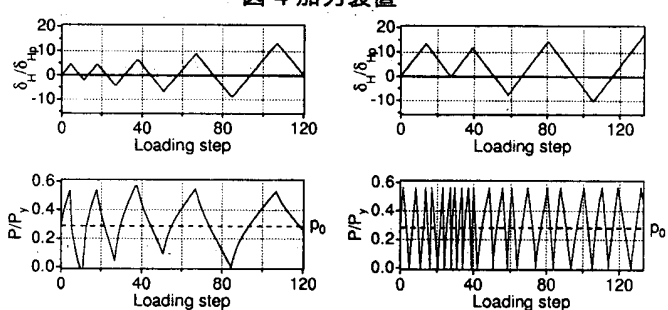

A-OV-1 (2) A-UD-1
図 5 柱軸力の載荷パターン 
弾塑性骨組解析に用いる部材モデルとして, 部材を材端の弾塑 性要素と材中間部の弾性要素に置換する方法が提案されており, マルチスプリングモデル6), 弾塑性ジョイントモデル2)等と呼ばれ ている. 変動軸力と水平荷重を受ける部材の水平荷重と水平変位 に関する荷重変形関係について,このモデルによる解析結果と実 験結果はよい対応を示すことが報告されている21,6)．解析において は弾塑性要素の長さを仮定する必要があるが，筆者等の経験では， 水平変位と水平荷重の関倸についての解析においては弾塑性要素 の長さが解析結果に及ぼす影響は小さく，例えば断面せい程度の 長さを仮定して解析を行うことができる．しかし軸変形について は弾塑性要素の長さが解析結果に影響を与えるため, 軸変形につ いての解析はこの様なモデルでは限界があると考えられる.

本解析に用いる部材モデルは, 上記のモデルを拡張したもので, 材端に複数個の弾塑性要素を設けることとしている．これにより， 軸力比が高く部材の塑性域が材中央付近まで広がる場合も含めて 水平変位および軸変位に関する荷重変形関倸の解析が可能となる.

\section{2 解析上の仮定}

解析における基本的仮定は以下である.

(1) 断面の歪分布は変形後も平面を保持する.

(2) 降伏に対するせん断応力の影響は無視する.

(3) せん断変形は弾性剛性を用いて求める.

3.3 部材モテル

図6に示す様に複数個の弾塑性要素と弹性要素から成る部材モデ ルを考える.

\section{(1) 弾塑性要素}

弾塑性要素は図7に示す様に曲げ軸に平行な線で有限個の微小断 面に分割し，それぞれの重心位置に各微小断面の断面積が集中し ているものとする. 微小断面要素の歪は要素中央位置における值 で代表させる.すなわち，微小断面要素の歪は材長方向で一定と する.

弾塑性要素の両端を $i, j$ とし $, i, j$ の力と変位が図9の様であ れば，力の増分と変位増分の関係は次式で表される。

$$
\left\{\begin{array}{c}
\Delta \mathbf{F}_{i} \\
\Delta \mathbf{F}_{j}
\end{array}\right\}=\left[\mathbf{K}^{\prime}\right]\left\{\begin{array}{l}
\Delta \mathbf{x}_{i} \\
\Delta \mathbf{x}_{j}
\end{array}\right\}
$$

ここで, $\left[\mathbf{K}^{\prime}\right]=[c]\left[k^{\prime}\right][c]^{T}$

$$
\begin{aligned}
& \text { で, }\left[\mathbf{K}^{\prime}\right]=[c]\left[k^{\prime}\right][c]^{T} \\
& \Delta \mathbf{F}_{i}=\left\{\begin{array}{l}
\Delta F_{x i} \\
\Delta F_{y i} \\
\Delta M_{i}
\end{array}\right\}, \quad \Delta \mathbf{x}_{i}=\left\{\begin{array}{l}
\Delta x_{i} \\
\Delta y_{i} \\
\Delta \theta_{i}
\end{array}\right\}, \quad[c]=\left[\begin{array}{ccc}
1 & 0 & 0 \\
0 & -1 & 0 \\
\ell / 2 & 0 & 1 \\
-1 & 0 & 0 \\
0 & 1 & 0 \\
\ell / 2 & 0 & -1
\end{array}\right], \\
& {\left[k^{\prime}\right]=\frac{1}{\ell}\left[\begin{array}{ccc}
k_{s} & 0 & 0 \\
0 & k_{11}^{\prime} & k_{12}^{\prime} \\
0 & k_{12}^{\prime} & k_{22}^{\prime}
\end{array}\right]}
\end{aligned}
$$

$k_{S}=G \cdot A_{s}, G$ : せん断弾性係数, $A_{s}$ : 有効せん断断面積,

$k_{11}^{\prime}=\sum E_{s}^{\prime} a_{s}, k_{12}^{\prime}=\sum E_{s}^{\prime} r_{s} a_{s}, k_{22}^{\prime}=\sum E_{s}^{\prime} r_{s}^{2} a_{s}, a_{s}$ : 微小断面要素 $s$ の断面積, $r_{s}$ : 同断面中心の図心からの距離(図7), $E_{s}^{\prime}=\Delta \sigma_{s} / \Delta \varepsilon_{s}$

なお, 有効せん断断面積 $A_{s}$ はウェブ部分の断面積とする.

\section{(2) 弾性要素}

弾性要素の力と変位の関係は(1)式と同様に増分式で表せば次式 となる.

$$
\left\{\begin{array}{c}
\Delta \mathbf{F}_{i} \\
\Delta \mathbf{F}_{j}
\end{array}\right\}=\left[\begin{array}{ll}
\mathbf{K}_{i i} & \mathbf{K}_{i j} \\
\mathbf{K}_{j i} & \mathbf{K}_{j j}
\end{array}\right]\left\{\begin{array}{l}
\Delta \mathbf{x}_{i} \\
\Delta \mathbf{x}_{j}
\end{array}\right\}
$$
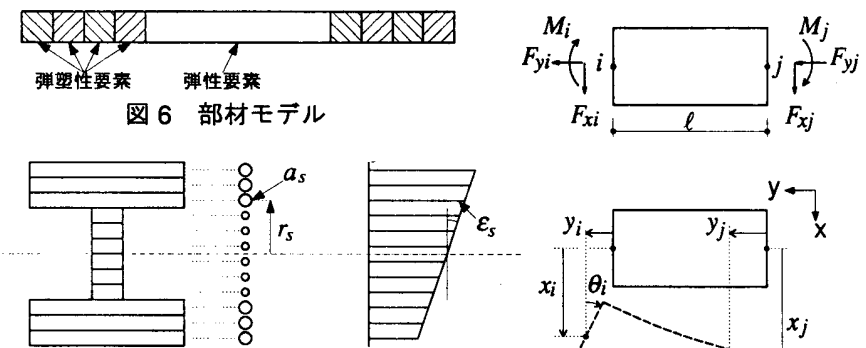

図 7 断面の分割

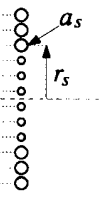

図 8 歪分布

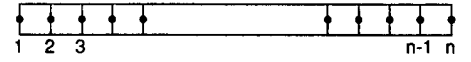

$$
\begin{aligned}
& \mathbf{K}_{i i}=\left[\begin{array}{ccc}
k_{1} & 0 & \frac{\ell}{2} k_{1} \\
0 & k_{2} & 0 \\
\frac{\ell}{2} k_{1} & 0 & \frac{\ell^{2}}{4} k_{1}+k_{3}
\end{array}\right], \mathbf{K}_{j j}=\left[\begin{array}{ccc}
k_{1} & 0 & -\frac{\ell}{2} k_{1} \\
0 & k_{2} & 0 \\
-\frac{\ell}{2} k_{1} & 0 & \frac{\ell^{2}}{4} k_{1}+k_{3}
\end{array}\right] \\
& \mathbf{K}_{i j}=\left[\begin{array}{ccc}
-x^{\prime} \\
-k_{1} & 0 & \frac{\ell}{2} k_{1} \\
0 & -k_{2} & 0 \\
-\frac{\ell}{2} k_{1} & 0 & \frac{\ell^{2}}{4} k_{1}-k_{3}
\end{array}\right], \mathbf{K}_{j i}=\mathbf{K}_{i j}{ }^{2} \\
& 1 \\
& k_{1}=\frac{\frac{\ell}{G A_{s}}+\frac{\ell^{3}}{12 E I},}{12 E}=\frac{E A}{\ell}, k_{3}=\frac{E I}{\ell}, I: \text { 断面2次モーメント }
\end{aligned}
$$

(3) 部材

ひとつの部材が図10に示す様に1個の弾性要素と $n-2$ 個の弾塑性 要素とから成っており，各要素端部の番号が $1,2, \cdots, n$ であるとする. 各要素の剛性行列を重ね合わせて部材全体の剛性行列をつくり,

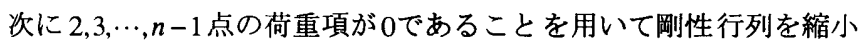
すれば，(3)式の様な $1, n$ 点に関する動合い式が得られる。

$$
\left[\begin{array}{ll}
\overline{\mathbf{K}}_{11} & \overline{\mathbf{K}}_{1 n} \\
\overline{\mathbf{K}}_{n 1} & \overline{\mathbf{K}}_{n n}
\end{array}\right]\left\{\begin{array}{l}
\Delta \mathbf{x}_{1} \\
\Delta \mathbf{x}_{n}
\end{array}\right\}=\left\{\begin{array}{l}
\Delta \mathbf{F}_{1} \\
\Delta \mathbf{F}_{n}
\end{array}\right\}
$$

(3)式では $P \delta$ 効果が考慮されていない.ここでは $P \delta$ 効果による部 材の付加モーメントは直線分布であると仮定し，(3)式を(4)式の様 に修正する，軸力が変動する場合を扱うので， $\Delta P$ に関する(4)式左 辺の第3項を考慮する必要がある.

$$
\begin{aligned}
& {\left[\begin{array}{ll}
\overline{\mathbf{K}}_{11} & \overline{\mathbf{K}}_{1 n} \\
\overline{\mathbf{K}}_{n 1} & \overline{\mathbf{K}}_{n n}
\end{array}\right]\left\{\begin{array}{l}
\Delta \mathbf{x}_{1} \\
\Delta \mathbf{x}_{n}
\end{array}\right\} }+\frac{P}{L}\left[\begin{array}{cc}
\mathbf{B}_{1} & -\mathbf{B}_{1} \\
-\mathbf{B}_{1} & \mathbf{B}_{1}
\end{array}\right]\left\{\begin{array}{l}
\Delta \mathbf{x}_{1} \\
\Delta \mathbf{x}_{n}
\end{array}\right\} \\
&+\frac{\Delta P}{L}\left[\begin{array}{cc}
\mathbf{B}_{1} & -\mathbf{B}_{1} \\
-\mathbf{B}_{1} & \mathbf{B}_{1}
\end{array}\right]\left\{\begin{array}{l}
\mathbf{x}_{1} \\
\mathbf{x}_{n}
\end{array}\right\}=\left\{\begin{array}{l}
\Delta \mathbf{F}_{1} \\
\Delta \mathbf{F}_{n}
\end{array}\right\} \cdots \cdots \cdots(4) \\
& \text { ここで, } \quad \mathbf{B}_{1}=\left[\begin{array}{ccc}
-1 & 0 & 0 \\
0 & 0 & 0 \\
0 & 0 & 0
\end{array}\right], P=-F_{y 1}=F_{y n}(\text { 材の軸力) }, L: \text { 材長 }
\end{aligned}
$$

以上で柱材について $P \delta$ 効果を考虑した場合の部材の材端力と材端 変位の関係式が得られた．軸変位と軸力に関わる項を除けぼ梁材 の関係式が得られる.

\section{4 骨組の釣り合い式}

図11に示す様に全体座標系を $X, Y$ とし, 各階 床の $X$ 方向変位を $u$, 各節点の $Y$ 方向变位と回 転角をそれぞれ $v ， \theta$ とする。各部材について の剛性行列を重ね合わせて骨組全体の剛性行列 をつくり，次に節点にはモーメント外力が作用

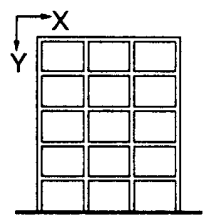

図11全体座標系

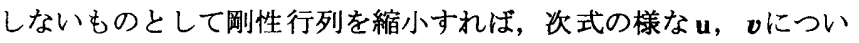
ての釣合い式が得られる。ここで， $\mathbf{F}_{x}$ は各階梁位置に作用する水 平荷重, $\mathrm{F}_{y}$ は各節点に作用する鉛直荷重で, それぞれ図11のX, Y 座標の向きを正とする. 
$\left[\begin{array}{ll}\mathbf{K}_{11}^{A} & \mathbf{K}_{12}^{A} \\ \mathbf{K}_{21}^{A} & \mathbf{K}_{22}^{A}\end{array}\right]\left\{\begin{array}{l}\Delta \mathbf{u} \\ \Delta \boldsymbol{v}\end{array}\right\}+\left[\begin{array}{cc}\mathbf{K}_{p} & 0 \\ \mathbf{0} & \mathbf{0}\end{array}\right]\left\{\begin{array}{l}\Delta \mathbf{u} \\ \Delta \boldsymbol{v}\end{array}\right\}+\left[\begin{array}{cc}\mathbf{K}_{\Delta p} & \mathbf{0} \\ \mathbf{0} & \mathbf{0}\end{array}\right]\left\{\begin{array}{l}\mathbf{u} \\ \boldsymbol{v}\end{array}\right\}=\left\{\begin{array}{l}\Delta \mathbf{F}_{x} \\ \Delta \mathbf{F}_{y}\end{array}\right\} \cdots(5)$ 3.5 鉛直荷重と水平変位を受ける場合の解

実験では鉛直載荷は荷重で，水平載荷は変位で制御している．u と $\mathbf{F}_{y}$ を与えて $\boldsymbol{v}$ と $\mathbf{F}_{x}$ を求める解析法を以下に示す。

あるステップ $s$ ま゙の荷重 $\mathbf{F}_{x}, \mathbf{F}_{y}$ 変位 $\mathbf{u}, \boldsymbol{v}$ が定まっているとする. ステップsから $s+1$ 増分に対する钓り合い式において，既知量に 下線を付けて表わせば次の様である。

$\left[\begin{array}{ll}\frac{\mathbf{K}_{11}^{A}}{\mathbf{K}_{21}^{A}} & \frac{\mathbf{K}_{12}^{A}}{\mathbf{K}_{22}^{A}}\end{array}\right]\left\{\left\{\begin{array}{ll}\underline{\Delta \mathbf{u}} \\ \Delta \boldsymbol{v}\end{array}\right\}+\left[\begin{array}{ll}\frac{\mathbf{K}_{p}}{0} & 0\end{array}\right]\left\{\begin{array}{l}\frac{\Delta \mathbf{u}}{\Delta v \boldsymbol{v}} \\ 0\end{array}\right\}+\left[\begin{array}{ll}\frac{\mathbf{K}_{\Delta p}}{0} & 0\end{array}\right]\left\{\begin{array}{l}\underline{\mathbf{u}} \\ \underline{v}\end{array}\right\}=\left\{\begin{array}{l}\Delta \mathbf{F}_{x} \\ \Delta \mathbf{F}_{y}\end{array}\right\} \cdots(6)\right.$ ここで, 1) $\underline{\underline{u}}$, v $\boldsymbol{v}$ はステップsのときの值とする.

2) $\underline{\mathbf{K}_{11}^{A}}, \underline{\mathbf{K}_{12}^{A}}, \mathbf{K}_{21}^{A}, \mathbf{K}_{22}^{A}$ はステップ $s$ のときの応力歪の状熊に おける瞬間剛性を用いて定める。

(6)式より $\Delta \mathrm{F}_{X} ， \Delta v$ を求めるこ,とができる.

3.6 応力と歪の関係

解析に用いる応力歪関倸のスケルトンカーブは，圧縮側は短柱 圧縮試験結果を引張側は引張素材試験結果を基に折線で表現する (4.1(3)参照). 履歴特性モデルとして以下の様な高梨・大井モデル》 を用いる. 図12に示す様に, 例えぼ正側に新たな塑性歪增分 $\Delta \varepsilon_{p}$ が 生じたのち歪増分の向きが逆転する場合は, 負側のスケルトンの

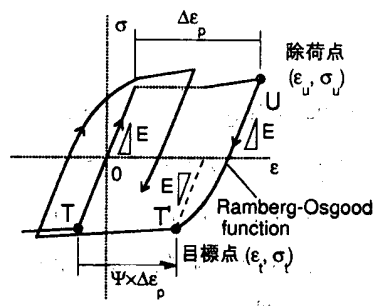

前回の弾性除荷点(T)から歪の負の 方向の部分を歪の正方向に $\Psi \cdot \Delta \varepsilon_{p}$ だけ平行移動し，今回の除荷点 $(\mathrm{U})$ と移動した負側のスケルトンの開始 点(T')を式(7)のRamberg-Osgood関数 で結ぶことにより負側に歪が進行す るときの応力歪関係がつくられる。 $\left(\sigma-\sigma_{u}\right)\left\{a+b\left|\sigma-\sigma_{u}\right|^{r-1}\right\}$

式(7)でrは曲線の丸みを变えるパラメータである。 bは，曲線が目橝点(T)を通ること，除荷点(U)の勾配が 率)であることの2つの条件から定められる゙。

\section{4 ，実験結果および解析結果}

本研究では，局部座届による耐力劣化が生じない範囲の挙動に ついて検討する. 実験結果および解析結果を図13(1)〜(13)に示す.

各試験体について以下の結果を示している.

・軸力の載荷履歴

・柱頭の水平変位の履歴

・柱頭の水平変位と水平荷重の関倸

・柱頭の水平変位と鉛直変位の関係

図中の実線は実験結果，破線は解析結果である。これらの表示に おいて以下の記号を用いている。

$P$ : 柱に作用する軸力， $Q$ : 柱に作用する水平荷重

$\delta_{H}$ : 柱頭の水平変位, $\quad \delta_{V}:$ 柱頭の鉛直変位

$P_{y}$ : 降伏軸力 $\left(=A_{C} \cdot \sigma_{y c}\right), \quad \sigma_{y c}:$ 柱材降伏点

$Q_{p}=M_{C_{P_{0}}} / L_{C}^{\prime}$

$\boldsymbol{\delta}_{H p}=\int\left(\frac{L_{C}^{\prime 2}}{3 E I_{C}}+\frac{1}{A_{S C} G}\right) M_{C_{P D}}$,

(A type) $\left\{\left[\frac{L_{C}^{\prime 2}}{3 E I_{C}}+\frac{1}{A_{S C} G}+\frac{L_{C}}{L_{G}}\left(\frac{L_{G}^{\prime 2}}{3 E I_{G}}+\frac{1}{A_{S G} G}\right)\right] M_{C_{P_{0}}}\right.$, (B type)

$\delta_{V y}=L_{C}^{\prime} \cdot \sigma_{y c} / E$

$M_{C_{P i j}}$ : 軸力が存在しないときの柱全塑性モーメント

$L_{C}^{\prime}= \begin{cases}L_{C} & \left.\text { (A type), } L_{G}^{\prime}=L_{G}-65 \mathrm{~mm} \quad \text { (B type }\right)\end{cases}$ $\left\{L_{C}-65 \mathrm{~mm} \quad\right.$ (B type)

$I_{C}$ : 柱の断面2次モーメント， $I_{G}$ : 梁の断面2次モーメント

$A_{C}$ : 柱断面積, $A_{S C}, A_{S G}$ : 柱, 梁の有効せん断断面積
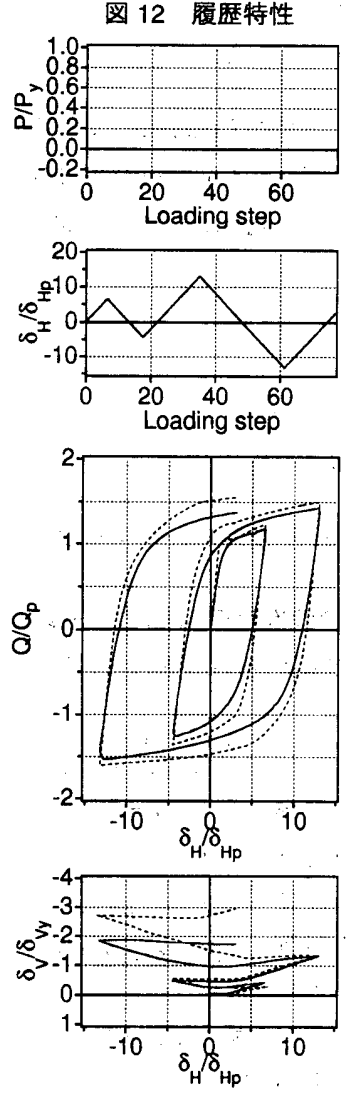

(1) A-C-1
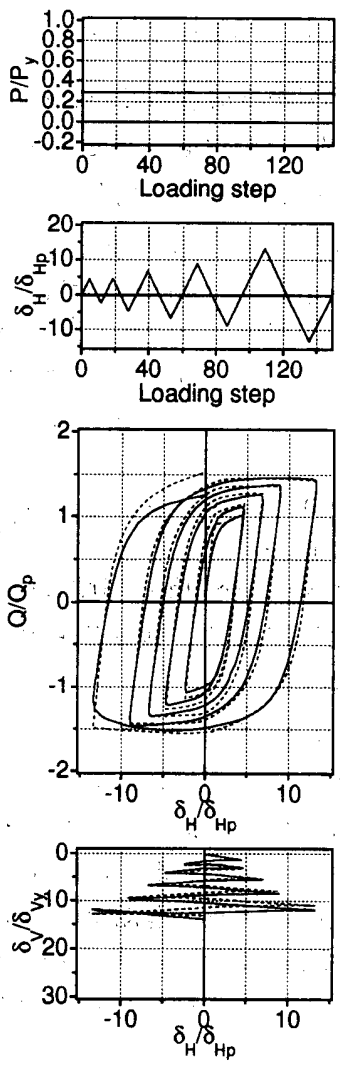

(2) A-C-2
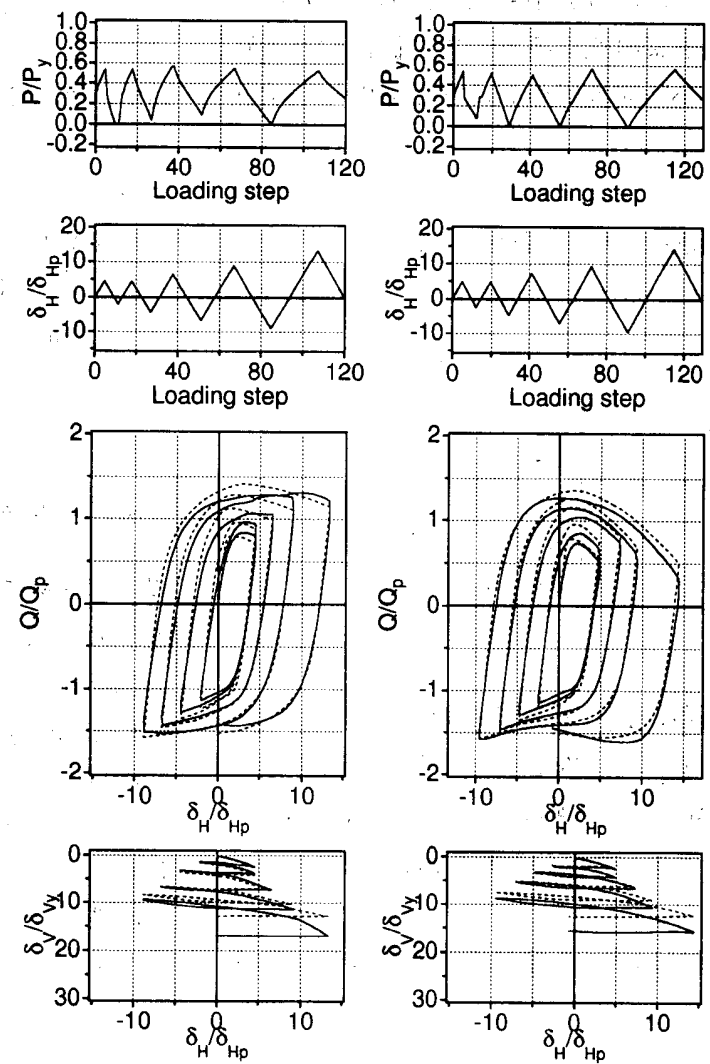

(3) A-OV-1
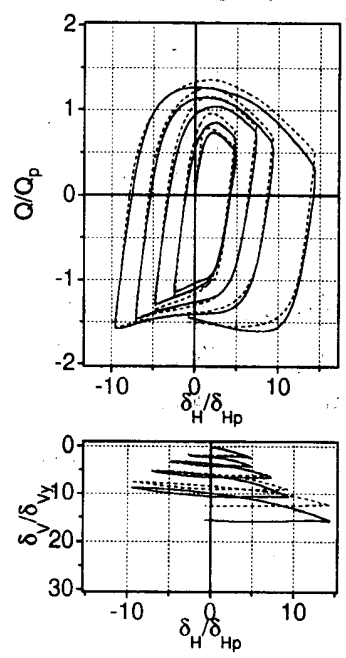

(4) A-OV-2
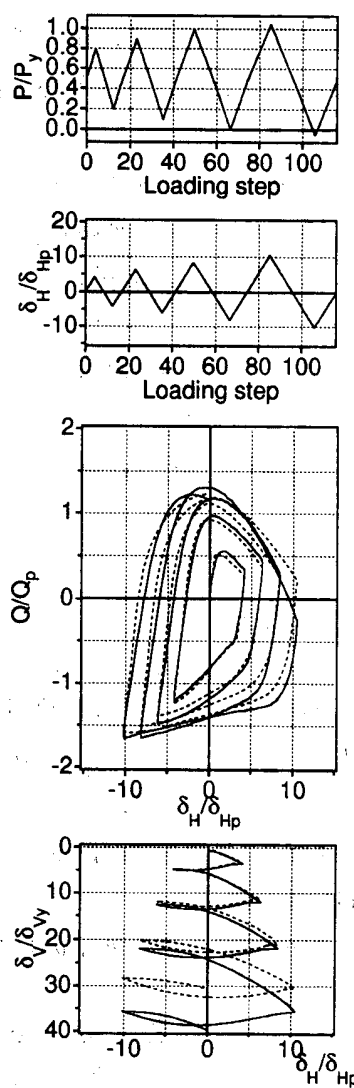

(5) A-OV-3

図13 実験結果 

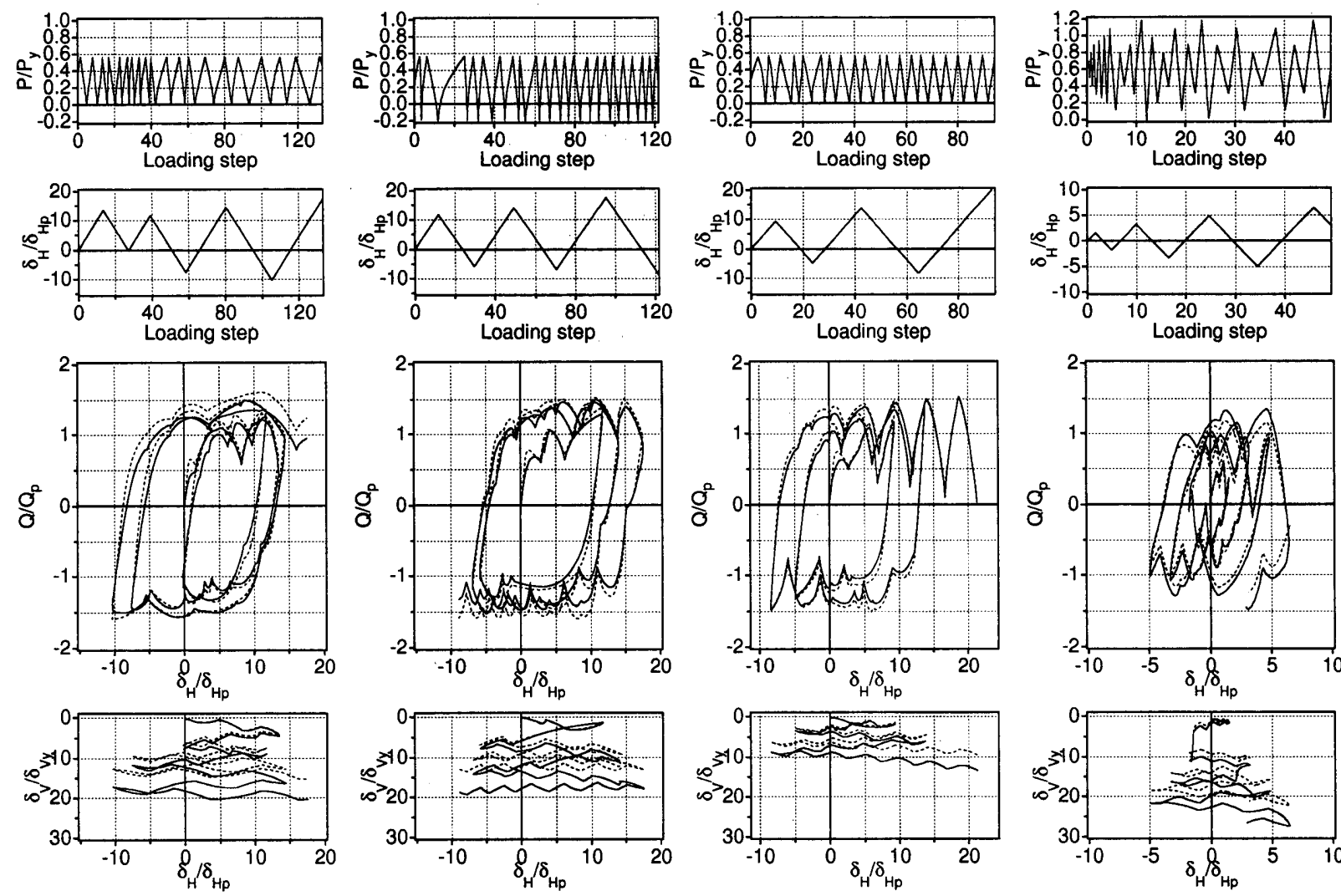

(7) A-UD-2
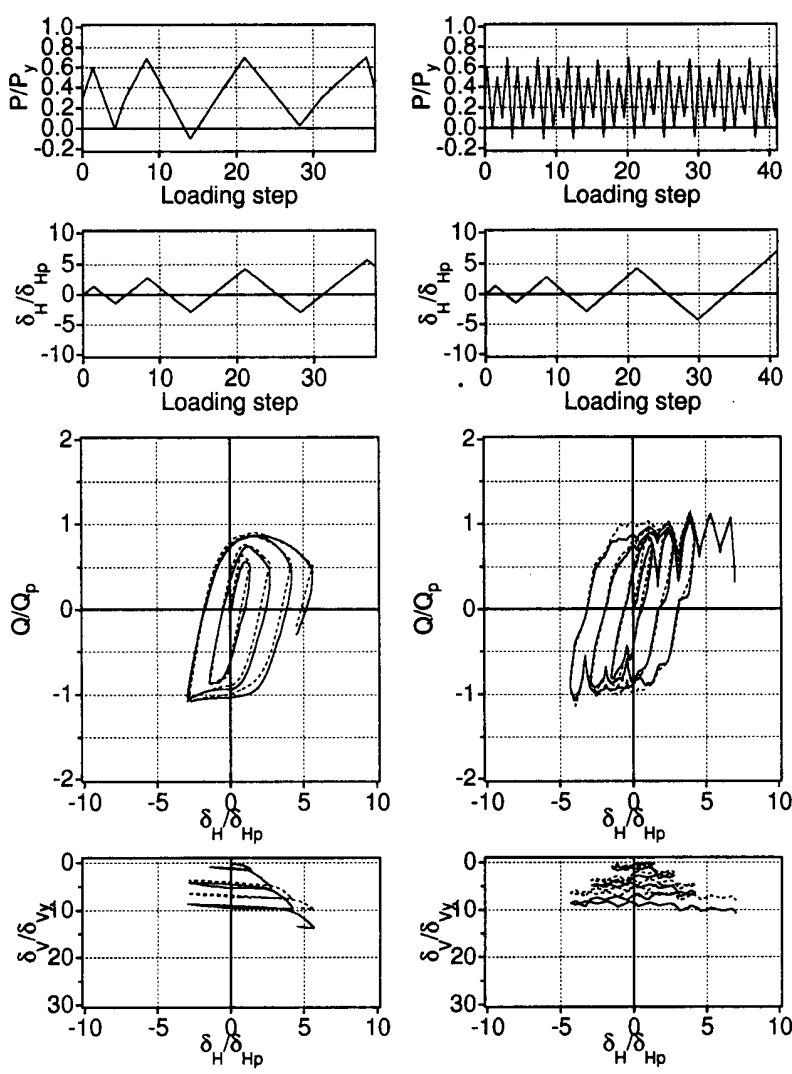

(10) B-OV-1
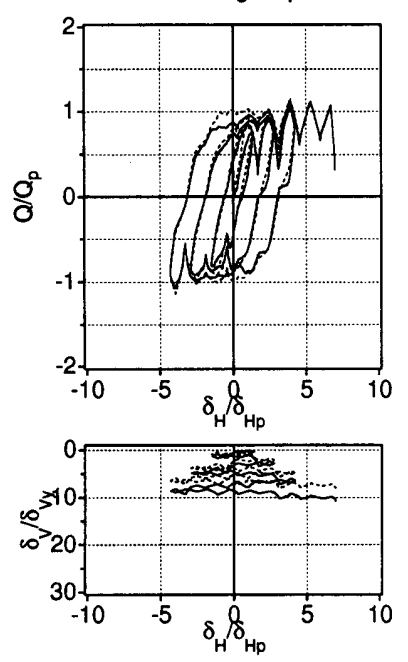

(11) B-UD-1
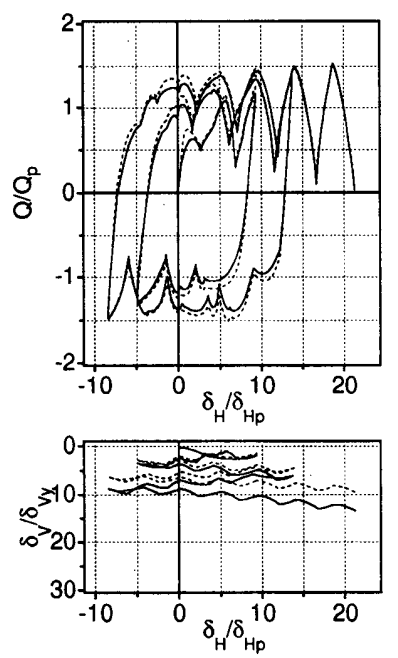

(8) A-UD-3
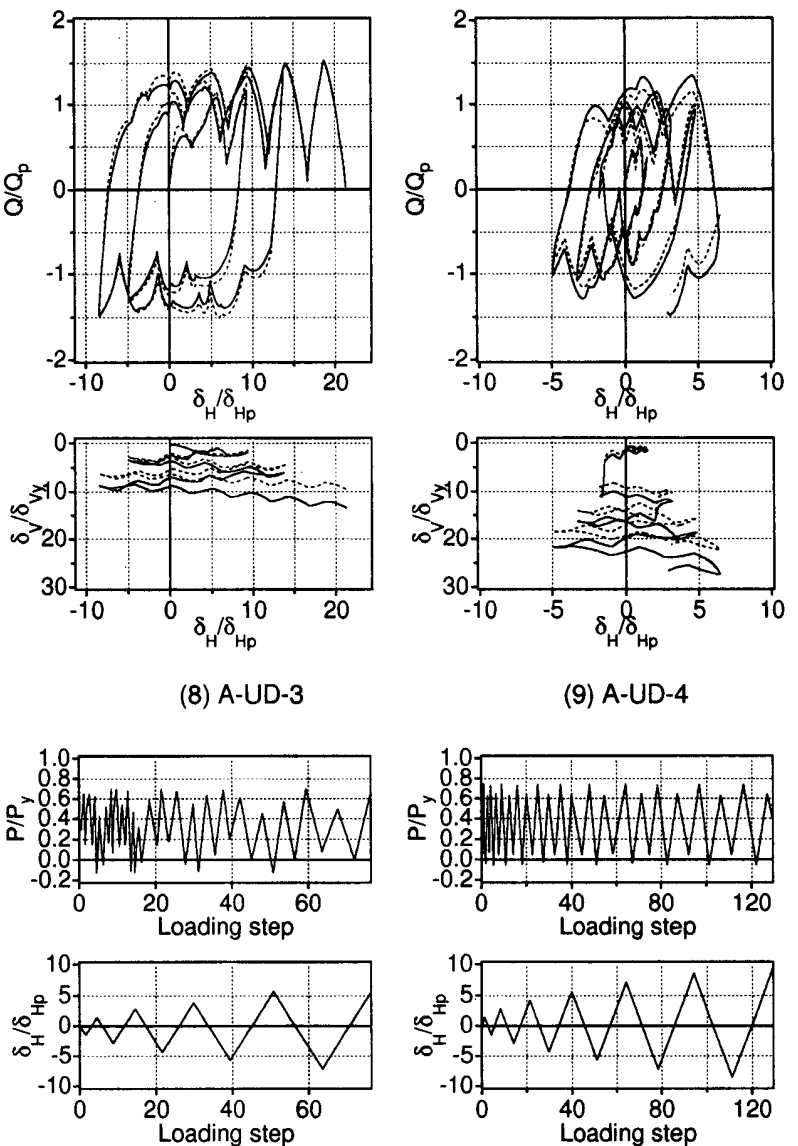

(9) A-UD-4
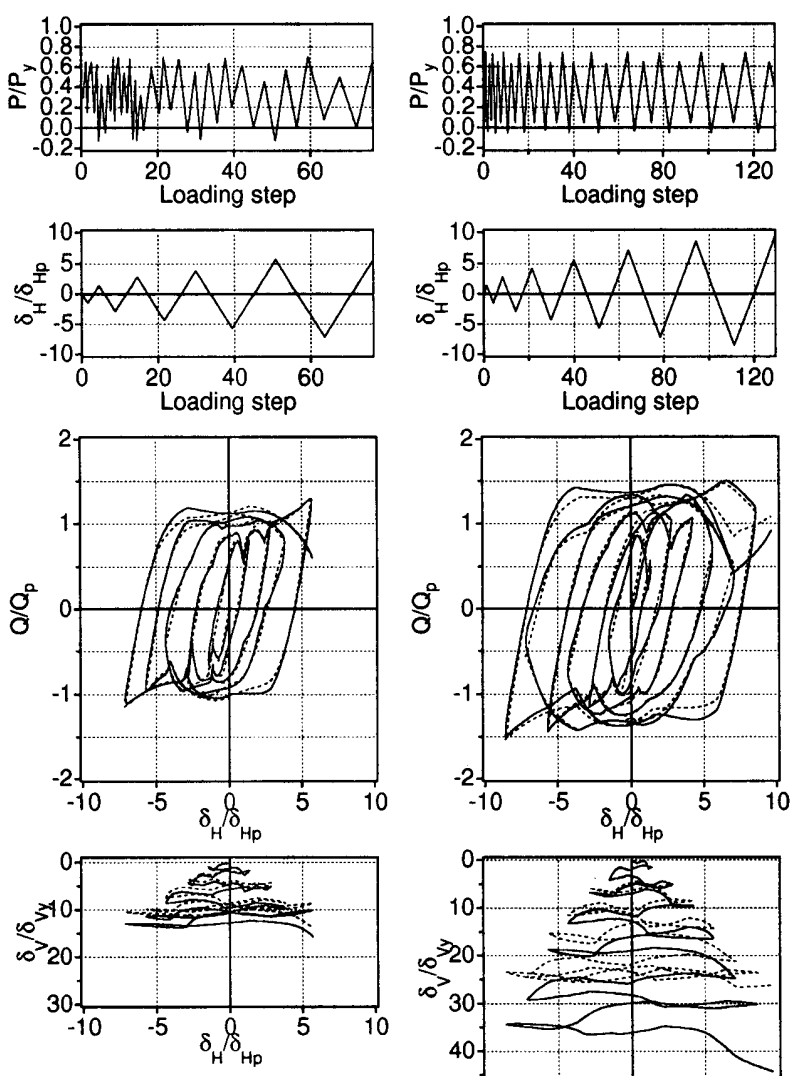

(12) B-UD-2

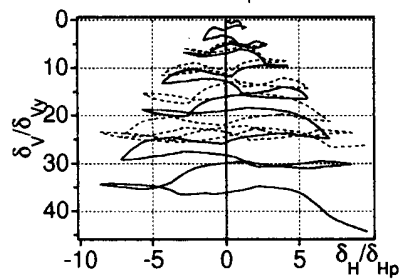

(13) B-UD-3

図13 実験結果(続き) 


\section{1 解析条件}

(1) 部材の分割

本実験では，柱材の場合，剛域を除く材全長が降伏する場合が あるので可撓長さを6分割 $\left(L_{C}=450,550\right)$ おび10分割 $\left(L_{C}=700\right)$ し総 てを弾塑性要素とした。梁材の場合は柱と接続する側の可撓長さ の1/3の区間について5分割しこの部分に弹塑性要素を角い,“残りの 区間は1個の弾性要素とした。

(2) 断面の分割

柱，梁断面の分割は；フランジ，ウェブ共に6分割とした.

(3) 応力歪関係

圧縮側：短柱圧縮試験における最大応力 $\sigma_{B}$ は一様に圧縮力を 受ける場合に局部座屈で決る応力であり, 軸力と曲げを受ける材 の最大応力は $\sigma_{B}$ より高くなる。 また, 局部座屈発生後の応力歪関 係の勾配についても；短柱圧縮試験の場合と，軸力と曲げを受け る材の場合とでは異なったものとなる 塑性要素(弾塑性ジョイシト)を構成する各ばねの復元力特性を設定 するに際して, 局部座屈で決る最大応力, および最大応力に至る までの塑性勾配および最大応力に達した後の劣化域の勾配は, 解 析值が定軸力の単調載荷実験に適合する様に試行錯誤で決められ ている.

本研究では，先に述べた様に局部座屈による酎力劣化が生じな い範囲の挙動を検討対象としているので, 解析に用いる応力歪関 㐿を次の様に設定した。すなわち, 短柱圧縮試験の最大応力に達 するまでは短柱圧縮試験から得られた応力歪関釈を4本の線分で近 似し, 最大応力に達した後の勾配は $980 \mathrm{~N} / \mathrm{mm}^{2}\left(=10 \mathrm{tf} / \mathrm{cm}^{2}\right)$ とした. 最終塑性勾配の大きさは, 解析值が実験值と対応する様に試行錯 誤により定めたものである.

引張側：引張素材試験から得られた応力歪関㐿を5本の線分で 近似したものを用いた。

圧縮側, 引張側について, 解析に用いた応力歪関係を図3に破線 で示している.

履歴特性に関するパラメータ $\Psi($ 図 12)とRamberg-Osgood関数の倸 数 $r($ (7)式) は, 一定軸力の試験体に対し解析值が実験值に適合す る様試行錯誤により求め, それぞれ $0.8,7.0$ とした.

4.2 Aタイプ試験体の挙動

（1）軸力載荷パターンC(一定軸力; A-C-1, A-C-2)

図13(1)，(2)が一定軸力の場合の結果で，それぞれの軸力比は
$0.0,0.29$ である。軸力が存在しない試験体A-C-1の 場合では，降伏後は中立軸が庄縮側に移動し材長 が増加する．なぜなら，降伏後はポアソン比が 0.5 となり圧縮側は断面が増加し，引張側は断面が堿 少するからである．従って正負の塑性綶返し曲げ を受けるとき材長が徐々に増加する．解析におけ る応力歪関係は，压縮側，引張側についてそれぞ れ短柱圧縮試験，引張素材試験による公称応力公 称歪関係に基づき定めている，従って，ポアソン 比による断面積変化の影響が考慮されていること になり，上記の現象は解析結果にも現れている.

（2）軸力載荷パターンOV(A-OV-1, A-OV-2, A-OV-3)

図13(3) (5)が転倒モーメントによる変動軸力を 想定した場合の結果である．長期荷重軸力に相当
する軸力を中心とする変動軸力を水平変位と同位相で加えている. A-OV-1とA-OV-2の場合を比較すると, いずれも, 平均軸力比が 0.29 で軸力変動幅はほほ一定(軸力比で士0.29)としているが，細長 比は前者が20, 後者が 31 である.. 荷重変形関係を見ると, 細長比 の大きいA-OV-2の方がP効果による耐力劣化が犬きく現れている. A-OV-3.場合は, 平均軸力比を $0.5 と し ：$ 変動軸力の大きさは繰返 し回数に伴い漸增させている. A-OV-1とA-OV-3の場合を比較する と, 細長比については両者でほぼ同じであるが, 軸力比は平均, 変動幅共にA-OV-3の方が大きく, また, 断面形の違いから局部座 屈で決る最大応力はA-OV-3の方が小さい，従って， $\delta_{H}$ が正の領域 において、 A-OV-3の方が耐力が低下している.

（3）軸力載荷パターンUD(A-UD-1, A-UD-2, A-UD-3, A-UD-4)

図13(6)〜(9)が鉛直振動による変動軸力を想定した場合の結果で

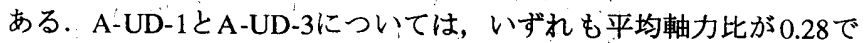
一定の変動幅(軸力比で \pm 0.28$)$ としているが, 細長比が異なり, 前 者は20, 後者は31である. 細長比の大きいA-UD-3の方が高軸力と なった瞬間の耐力の低下が大きいことが分かる．A-UD-2は平均軸

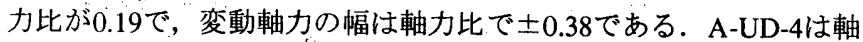
力比で平均 0.59 , 変動幅は最大で士0.59であり, 軸力比が 1.0 を数回 越えている. 4つの試験体共荷重変形関係は変動軸力の影響でかな り複雑な形となっている.

\section{3-Bタイプ試験体の挙動}

(1) 柱と梁の曲げ耐力および水平変位増分における柱成分の比率

Bタイプ試験体の柱断面はすべて同一のC1であるが, 梁断面はBUD-3がG2他はG1である．柱梁断面の全塑性モーメントを図 14に示 す. 図の実線は柱の全塑性モーメントと軸力の関係を無次元表示 したもので， $M_{C_{p_{0}}}$ は軸力が存在しないのときの柱の全塑性モーメ シトである. 破線は, 梁断面 $\mathrm{G} 1, \mathrm{G} 2$ の全塑性モーメットを $M_{C_{p_{0}}}$ で 除した值を示している：また図中に軸力変動の範囲を示している。 柱の全塑性モーメントを $M_{C_{p}}$, 梁の 全塑性モーメントを $M_{G p}^{\vdots}$ とすれば, 梁断面がG1の場合は, $P / P_{Y}<0.32$ の とき $M_{C_{p}}>M_{G_{p}}, P / P_{Y}>0.32$ のをき $M_{C_{p}}<M_{C_{p}}$ であるので, 軸力の変動 に伴い柱降伏と梁降伏が交互に現れ る. 梁断面が $\mathrm{G} 2$ の場合は $M_{C p}<M_{G p}$ であるが, 柱の塑性化が進行した段

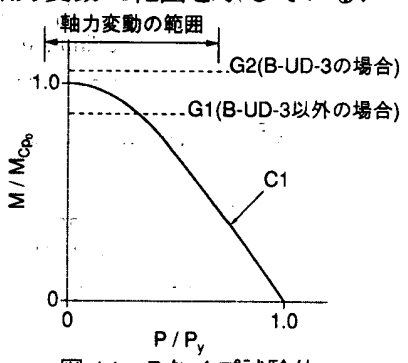

図 14 Bタイプ試験体 柱，梁の曲げ䞂力
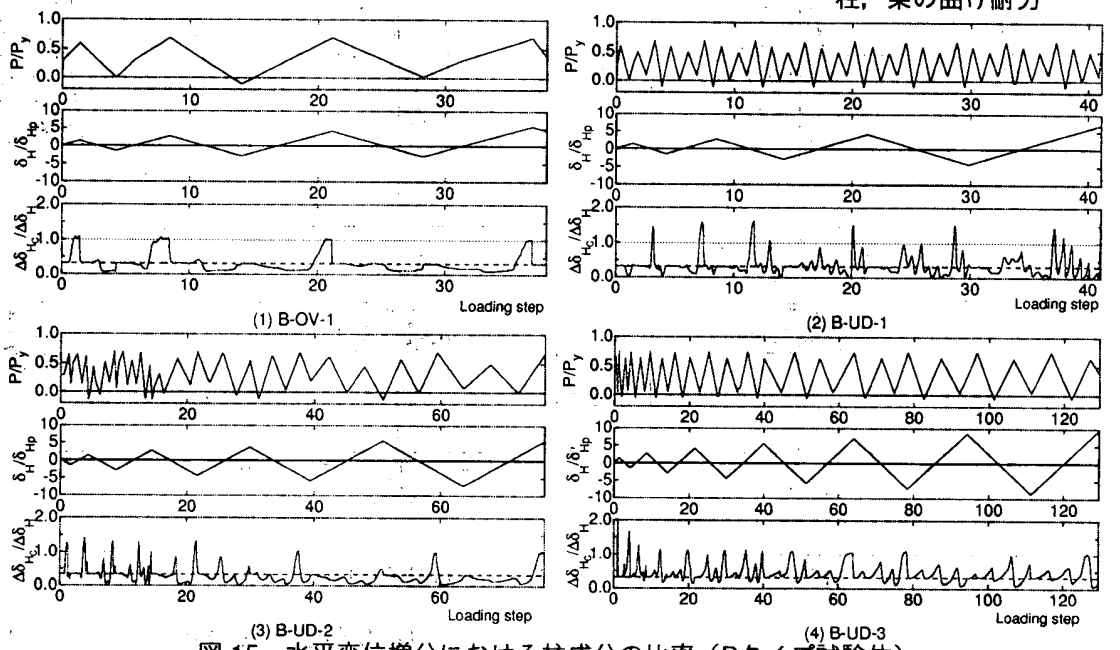

图 15 水市変位增分における柱成分の比率（Bタイプ試験体） 
階では歪硬化により曲げ耐力が上昇し梁断面も 降伏する場合が生じる.

図15(1)〜(4)はBタイプ試験体について水平変 位增分における柱成分の比率について調べたも のである. $\Delta \delta_{H_{C}}$ は各ステップにおける水平変 位増分のうち柱変形によるもので次式により求 めた.

$\Delta \delta_{H_{C}}=\Delta \delta_{H}-\Delta \theta \cdot L_{C}$

$\Delta \delta_{H}:$ 水平変位增分

$\Delta \theta:$ 柱梁交点の回転角の增分

弾性時の $\Delta \delta_{H_{C}} / \Delta \delta_{H}$ は, B-OV-1, B-UD-1, 2が 0.32, B-UD-3が0.31である.

（2）載荷パターンOV(B-OV-1)

図13(10)が部分架構モデルで転倒モーメント による変動軸力を想定した場合の結果である.

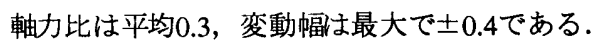
単一柱で軸力載荷パターンOVの場合と同様の 性状を示している.

図15(1)をみると，高軸力下で $\Delta \delta_{H_{C}} / \Delta \delta_{H}$ がほ
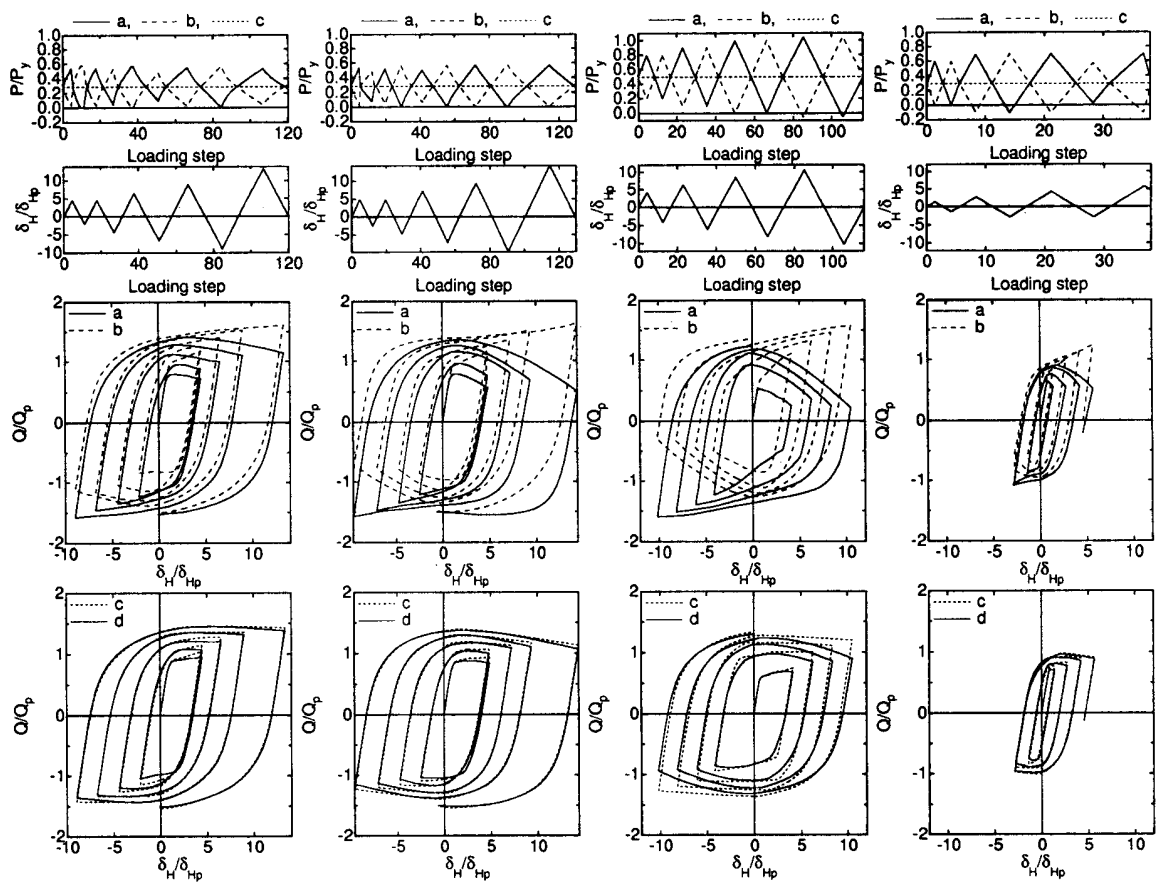

(1) A-OV-1

ぼ1となっている範囲があり，また，低軸力下で $\Delta \delta_{H_{C}} / \Delta \delta_{H}$ が 0 に近 づいている範囲がある．前者の場合の変位増分はそのほとんどが 柱の塑性変形によるものであり, 後者の場合は変位増分はそのほ とんどが梁の塑性変形によるものである.この様に軸力の変動に より柱と梁の降伏が交互に現れていることが分る。なお, $\Delta \delta_{H_{C}} / \Delta \delta_{H}$ が1を超える場合があるが, これは軸力の増加により柱 の抵抗モ一メントが低下し，これに伴い梁モーメントが除荷し $\Delta \delta_{H_{C}}>\Delta \delta_{H}$ となったためである.

（3）載荷パターンUD(B-UD-1，B-UD-2，B-UD-3)

図13(11)〜(13)が部分架構モデルで鉛直振動による変動軸力を想 定した場合の結果である. B-UD-1，B-UD-2は軸力比は平均 $0.3 て ゙$ 変

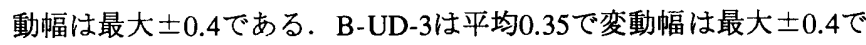
ある. 図15(2)〜(4)をみると，いずれの試験体においても柱と梁の 降伏が複雑に進行していることがわかる．載荷パターンUDの場合 はOVの場合に比べて軸力の変動が大きいので $\Delta \delta_{H_{C}} / \Delta \delta_{H}$ が1をかな り超える場合が生じている. B-UD-3は他の試験体に比べて梁の耐 力が高いので(図14参照), 柱による変形の占める比率がB-UD-1, 2 の場合より大きくなっていることが本図からも分る.

\section{4 実験結果と解析結果の比較}

水平変位と水平荷重の関係, 水平変位と鉛直変位の関係共に, 解析結果は変動軸力による複雑な挙動を示す実験結果とよく対応 しており，本解析法により，変動軸力と繰返し水平力を受ける平 面骨組の解析が可能であると考えられる. 本解析では, 応力歪関 係の最終勾配を正としている(4.1(3)，図3参照)，解析において圧縮 側の最大スケルトン歪はC1， C2，C3， G1，G2断面に対し，それ ぞれ0.18, $0.07,0.15,0.09,0.11$ となっているが, この様な歪を生 ビている状態に対しても実験結果と解析結果は対応していること から，耐力の劣化が生じていないと考えられる．局部座届による 耐力の劣化を考虑した変動軸力と絽返し水平力を受ける部材の挙 動についての検討は今後の課題である.

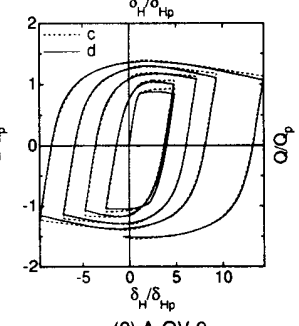

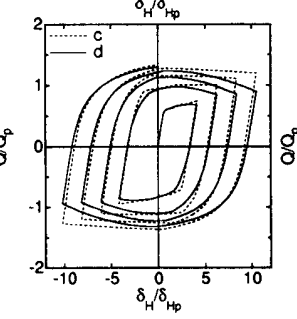

(3) A-OV-3
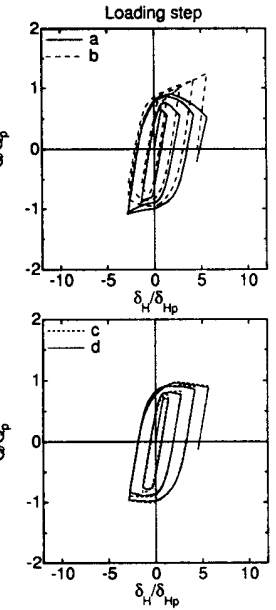

(4) B-OV-1
5 考察

5.1 転倒モーメントによる変動軸力が復元力特性に及ぼす影響

本解析法により部材の挙動が精度よく再現できることが確認さ れたので, 解析により転倒モーメントによる変動軸力が復元力特 性に及ぼす影響について検討する.

計4体の軸力載荷パターンOVの試験体について, それぞれ, 水 平変位の履歴は実験と同一とし, 以下に $\mathrm{a}, \mathrm{b}, \mathrm{c}$ で示す 3 種類の軸力 の履歴に対して解析を行った.
a. $P(s)=P_{0}+P_{O V}(s)$
b. $P(s)=P_{0}-P_{O V}(s)$
c. $P(s)=P_{0}$

ここで, $P(s):$ 載荷軸力, $s:$ 載荷ステップ

$P_{0}:$ 長期軸力に相当する一定軸力

$P_{O V}(s)$ :転倒モーメントにより生じると想定する変動軸力.

a.は実験における載荷履歴と同一とする. すなわち， $P_{0}$ は当該試 験体に載荷した軸力の平均値であり, $P_{O V}(s)$ は, 当該試験体の各ス テップの軸力から $P_{0}$ を差引いたものである.

各試験体に対する解析結果を図16(1) (4)に示す. 図中の曲線a, b, cはそれぞれ上記の $\mathrm{a}, \mathrm{b}, \mathrm{c}$ の軸力載荷に対応している. 荷重変形関係 の図における曲線 $\mathrm{d} は$ 同一変位における $\mathrm{a}$ と $\mathrm{b}$ 水平荷重の平均值を プロットしたものである，荷重変形関保における曲線 $\mathrm{c}$ とはいず れの試験体の場合についてもかなり接近していることが分かる. 従って, 軸対称な平面骨組の場合は, 転倒モーメントにより生じ る変動軸力が首の復元力特性に与える影響は小さいといえる.

5.2 鉛直地震動による变動軸力が層の復元力特性およびエネルギー 吸収量に及ほす影響

鉛直地震動による変動軸力は同一層の柱に対してはほぼ同位相 で加わると考えられるので, 層の復元力特性に及ぼす鉛直地震動 の影響は柱および部分架構の復元力特性に及ぼす変動軸力の影響 から推定することが出来ると考えられる.

計7体の軸力載荷パターンUDの試験体について，それぞれ水平 

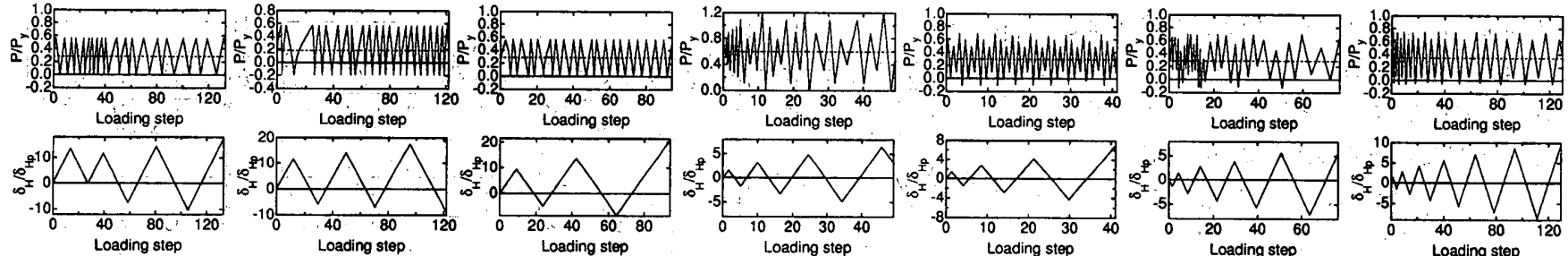

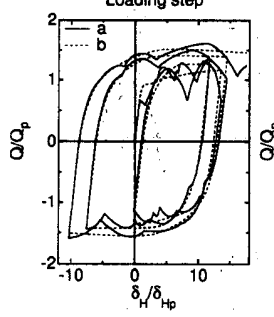

(1) A-UD-1

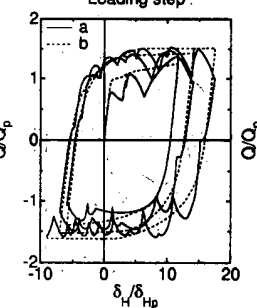

(2) A-UD-2

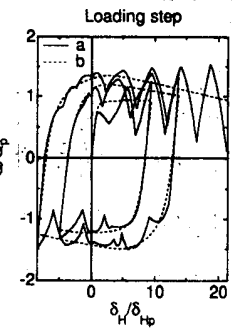

(3) A-UD-3

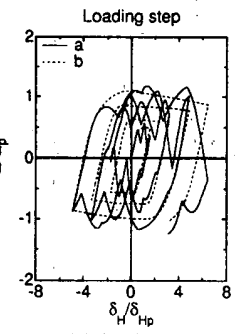

(4) A-UD-4
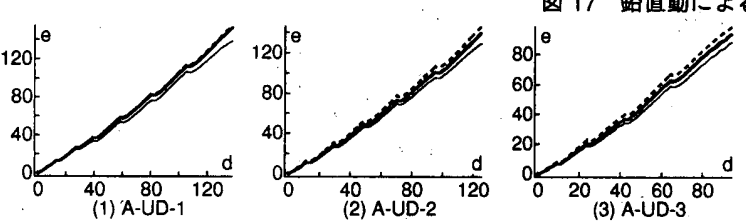

图 18 エネルギー吸収量

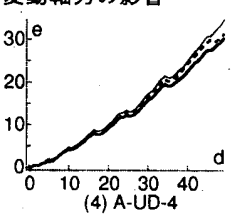

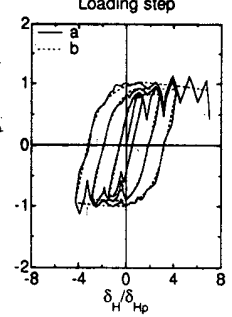

(5) B-UD-1

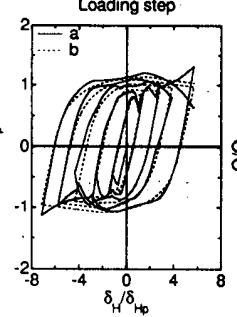

(6) B-UD-2

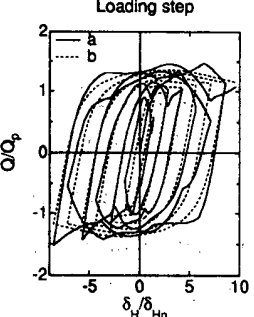

(7) B-UD-3

変位の履歴は実験の場合と同一とし，以下に $\mathrm{a}, \mathrm{b} て ゙$ 示す 2 種類の軸 力履歴に対して解析を行った.
a. $P(s)=P_{0}+P_{U D}(s)$
b. $P(s)=P_{0}$

ここで, $P_{U D}(s)$ :鉛直振動により生じると想定する変動軸力.

a.は実験における載荷履歴と同一とする. 各試験体に対する解析 結果を図17(1)〜のに示す.これらの図より, 変動軸力下の荷重変形 関係は複雑な形をしているが, 変動軸力下での耐力は概ねその平 均值で一定軸力のときの耐力を中心に変動していることが分かる.

次に, 一定軸力の場合と変動軸力の場合のエネルギー吸収量に ついて検討する。それぞれの場合について, 次式により吸収エネ ルギー(無次元量)を求める.

$$
\begin{aligned}
& e=\sum_{s}\left\{\left(\frac{Q}{Q_{p}}\right)_{s} \cdot \Delta\left(\frac{\delta_{H}}{\delta_{H p}}\right)_{s}\right\} \\
& \text { ここで, } \quad\left(\frac{Q}{Q_{p}}\right)_{s}: \text { 載荷ステップsにおける } \frac{Q}{Q_{p}}
\end{aligned}
$$

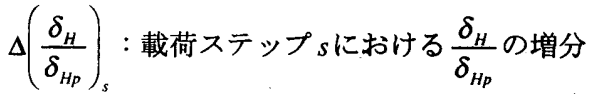

計算結果を図18(1)〜(7)に示す．同図の横軸は次式による $d$ である.

$$
d=\sum_{s}\left|\Delta\left(\frac{\delta_{H}}{\delta_{H P}}\right)_{s}\right|
$$

同図には実験結果より求めた $e$ も示している.これらの図より, 変 動軸力を受けるときの柱および部分架構のエネルギー吸収量はそ の平均值である一定軸力を受けるときのエネルギー吸収量と概ね 等しいことが分かる. 以上より, 鉛直振動による柱軸力の変動が 水平応答に与える影響は大きくないことが予想されるが，ここで の検討は変位制御による繰返し載荷時のものであり, 今後動的応 答に関する検討が必要である.

\section{6 結論}

変動軸力と繰返し水平力を同時に受ける柱および部分架構の弾 塑性挙動を明らかにすることを目的として, 軸力が, 一定の場合, 水平変位と同位相で変化する場合(転倒モーメントによる変動を想

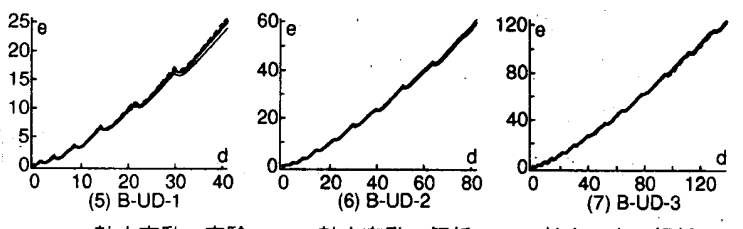

一軸力変動: 実酸

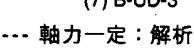

定), 水平変位の絽返し1サイクルに対し約5 10サイクル䋖返す場合 (鈶直振動による変動を想定)について実験を行うた．部材を複数の 弹塑性要素と弾性要素にモデル化する解析法を用いて, 部材の弾 塑性挙動が軸方向変位も含めて精度よく予測できることを示した.

本研究により，以下の結論を得た。

(1) 軸対称な平面骨組において, 転倒モーメントにより生じる変動 軸力が層の復元力特性に与える影響は小さい.

(2) 水平変位の綝返し1サイクルに対し変動軸力が約 5 〜 10サイクル 綝返す場合, 柱および部分架構のエネルギー吸収量は, 軸力が その平均值で一定であるときのエネルギー吸収量と概ね等しい.

謝辞 本研究の実験の実施にあたり東京都立大学大学院生森康行君, 東京 都立大学卒論生国府田正夫君, 東京電機大学卒論生渡䢟仁君の協力を得た。

\section{参考文献}

1) 例えば, Van Kuren, R. C. and Galambos, T. V. : Beam-Column Experiments, Journal of the Structural Division, ASCE, Vol.90, ST2, pp.223-256, 1964.4 加藤勉, 秋山宏 : 銅構造部材の耐力(その4), 日本建築学会論文報告集; 第15!号, pp.15-20, 1968.9

鈴木敏郎，小野徹郎ほか: '圧縮と曲げを受ける鉄骨柱の変形能力に関寸 る考察(1)，(2)，日本建築学会大会学術講演梗概集，1976.10

2) 大井謙一，陳以一，高梨晃一: : 変動軸力と水平力を受けるH形鋼柱の 弹塑性挙動に関する実験的研究，構造工学論文集Vol.38B, pp.421-430, 1992.3

3) 陳以一，大井謙一，高梨晃一：3方向変動荷重を受ける箱形断面鋼柱の 弹塑性挙動, 日本建築学会構造系論文報告集, 第447号, pp.139-148, 1993.5

4) 山田哲, 秋山宏, 桑村仁：局部座屈を伴う箱形断面鋼柱部材の変動軸 力下における終局挙動, 白本建策学会構造系論文集, 第 461 '号, pp.115-122, 1994.7

5) 見波進，山崎真司：鉛直地震動が多層建築の柱軸力に及ぼす影響，日 本建築学会大会学術講演梗概集, B-2, pp. 631--632, 1996.9

6) 李康寧, 小谷俊介, 青山博之：3軸変動力を受ける铁能コンクリート柱 の解析モデル, 構造工学論文集, Vol.33B, pp.169-178, 1987.3

7) 孟令樺, 大井謙一，高梨晃一：鉄骨骨組地震応答解析のための耐力劣 化を伴う簡易部材モデ, 日本建築学会論文報告集, 第437号, pp.115-124, 1992.7

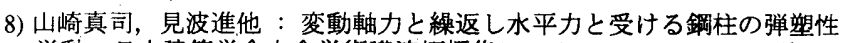
挙動, 日本建築学会大会学術講演梗概集, C-1 pp.343-346, 1996 (その 1, 2), C-1 pp.649-652, 1997 (その3，4)

(1998年 6 月15日原稿受理，1998年11月19日採用決定） 